\title{
Restoration of HCV-Specific Immune Responses with Antiviral Therapy: A Case for DAA Treatment in Acute HCV Infection
}

\author{
Julia L. Casey ${ }^{1}$, Jordan J. Feld ${ }^{1,2}$ and Sonya A. MacParland ${ }^{2,3, *(1)}$ \\ 1 Institute of Medical Science, University of Toronto, Toronto, ON M5S 1A8, Canada; \\ julia.casey@mail.utoronto.ca (J.L.C.); Jordan.Feld@uhn.ca (J.J.F.) \\ 2 Toronto General Hospital Research Institute, University Health Network, Toronto, ON M5G 2C4, Canada \\ 3 Departments of Laboratory Medicine \& Pathobiology and Immunology, University of Toronto, Toronto, \\ ON M5S 1A1, Canada \\ * Correspondence: s.macparland@utoronto.ca; Tel.: +1-416-581-7442
}

Received: 20 February 2019; Accepted: 30 March 2019; Published: 5 April 2019

check for updates

\begin{abstract}
Worldwide, 71 million individuals are chronically infected with Hepatitis C Virus (HCV). Chronic HCV infection can lead to potentially fatal outcomes including liver cirrhosis and hepatocellular carcinoma. HCV-specific immune responses play a major role in viral control and may explain why approximately $20 \%$ of infections are spontaneously cleared before the establishment of chronicity. Chronic infection, associated with prolonged antigen exposure, leads to immune exhaustion of HCV-specific T cells. These exhausted T cells are unable to control the viral infection. Before the introduction of direct acting antivirals (DAAs), interferon (IFN)-based therapies demonstrated successful clearance of viral infection in approximately $50 \%$ of treated patients. New effective and well-tolerated DAAs lead to a sustained virological response (SVR) in more than $95 \%$ of patients regardless of viral genotype. Researchers have investigated whether treatment, and the subsequent elimination of $\mathrm{HCV}$ antigen, can reverse this $\mathrm{HCV}$-induced exhausted phenotype. Here we review literature exploring the restoration of $\mathrm{HCV}$-specific immune responses following antiviral therapy, both IFN and DAA-based regimens. IFN treatment during acute HCV infection results in greater immune restoration than IFN treatment of chronically infected patients. Immune restoration data following DAA treatment in chronically $\mathrm{HCV}$ infected patients shows varied results but suggests that DAA treatment may lead to partial restoration that could be improved with earlier administration. Future research should investigate immune restoration following DAA therapies administered during acute $\mathrm{HCV}$ infection.
\end{abstract}

Keywords: Hepatitis C Virus; direct acting antivirals; DAAs; interferon; IFN; immune restoration; immune exhaustion; exhausted $\mathrm{T}$ cells

\section{Introduction}

\subsection{Natural History of Hepatitis C Virus (HCV) Infection}

The World Health Organization (WHO) estimates the prevalence of chronic hepatitis $\mathrm{C}$ virus (HCV) infection to be 71 million people worldwide [1]. Annually, 39,000 deaths are attributed to HCV infection [1]. These deaths are predominantly caused by outcomes of chronic infection including cirrhosis and hepatocellular carcinoma [1]. Approximately $15 \%-45 \%$ of those infected with HCV spontaneously clear viremia with the remaining $55 \%-85 \%$ advancing to chronic Hepatitis C (CHC) [2]. HCV chronicity is generally defined as HCV RNA positivity beyond 6 months [3], but is truly marked by the exhaustion of the immune response leading to failure of spontaneous $\mathrm{HCV}$ clearance [2]. Chronic 
$\mathrm{HCV}$ infection is usually a lifelong infection unless treated. Currently there is no preventative or therapeutic vaccine and treatment targets patients who are in the chronic phase of $\mathrm{HCV}$ infection and generally not those recently infected with HCV [4].

\subsection{Virus-Induced Immune Dysfunction}

The outcome of a viral infection can be either acute infection followed by control of viral replication and spontaneous clearance or viral persistence resulting in a chronic infection. Both host and viral characteristics influence the acute versus chronic outcome [5,6]. Many different cell types contribute to the elimination of viral infections such as $\mathrm{HCV}$ [7]. Both innate and adaptive immune responses are active during an $\mathrm{HCV}$ infection; however, in most cases $\mathrm{HCV}$ manages to escape these responses to establish chronicity.

The high variability in disease outcomes between immune competent individuals is not well understood, but several factors have been identified that influence an individual's ability to control HCV viral infection. Female sex, Aboriginal ethnicity [8] and younger age [9] are associated with increased rates of $\mathrm{HCV}$ clearance. In contrast, human immunodeficiency virus (HIV) coinfection and injection drug use are associated with increased $\mathrm{HCV}$ persistence [8]. Breadth, but not frequency, of HCV-specific $\mathrm{CD}^{+} \mathrm{T}$ cell responses are shown to be reduced in HIV/HCV co-infected individuals [10]. However, with improved treatment of both HIV and HCV infections, sustained virological response (SVR) outcomes for coinfected individuals demonstrate similar success [11]. Furthermore, a retrospective investigation of $\mathrm{HCV}$ infection found spontaneous clearance of $\mathrm{HCV}$ was more frequently documented among subjects with a history of icteric hepatitis and hepatitis B virus (HBV) coinfections [12].

Variation in genes involved in the host immune response have been found to influence an individual's ability to clear acute HCV infection. The rs12979860 CC genotype, a single nucleotide polymorphism (SNP) upstream of the IL28B gene, which encodes the type III interferon IFN- $\lambda$ has been shown to be a strong predictor of an effective response to IFN therapy for chronic HCV infection [5]. Individuals with the rs12979860 CC genotype are more likely to spontaneously clear HCV infection and respond to pegylated-interferon (PEG-IFN)- $\alpha$ /ribavirin(RBV) treatment $[5,13,14]$. The association between rs12979860 CC genotype and spontaneous resolution of HCV infection has been shown among individuals of both European and African ancestry [5] and confirmed in a Chinese population [15]. The major C allele of rs12979860 SNP in the general population has a frequency of $0.23-0.55$ among Africans, 0.53-0.80 among Europeans and 0.66-1.00 among Asians [16]. Accordingly, Asians and Europeans demonstrate higher response rates to combined peg-IFN- $\alpha$ and ribavirin therapy than African-descendants [17]. The strong correlation between this genotype, ethnic groups and control of $\mathrm{HCV}$ suggests the presence of a selective pressure exerted by environmental factors [18].

Following an inability to spontaneously clear HCV infection, the majority of cases succumb to a chronic infection [19]. Natural killer (NK) cells and macrophages play an important role in innate immune responses and become impaired in chronic HCV infection [20]. During chronic infection, activity of NK cells has also been reported to be impaired in patients with HCV infection [20]. The ability of NK cells to produce and secrete IFN- $\gamma$ is weakened after exposure to HCV-infected cells [21]. The decline of IFN- $\gamma$ production is consistent with the reduction of NK cell degranulation, demonstrating a reduced functional capacity of these NK cells [21]. The inhibition of NK cell function was associated with downregulation of NK-activating receptors on NK cell surfaces [21]. Inhibition of ex vivo NK functions with $\mathrm{HCV}$ infected cells corresponds with reduced surface expression of the natural cytotoxicity receptor NKp30 [22]. HCV NS5A protein has been shown to induce IL-10 and TGF- $\beta$ secretion in monocytes [23]. These cytokines also have a regulatory, suppressive effect on NK cell function.

HCV-specific $\mathrm{CD}^{+}{ }^{+} \mathrm{T}$ cells or cytotoxic T lymphocytes (CTLs) are required for the control of HCV infection [24]. The CTL response to acute HCV infection begins with the effector phase when naïve T cells are primed by HCV antigen, undergo expansion and facilitate clearance of infection by specifically killing infected cells. In the case of spontaneous clearance, this response is successful at clearing the 
$\mathrm{HCV}$ infection [25]. A small subset of these HCV-specific CD8 ${ }^{+} \mathrm{T}$ cells will persist as long-lived memory cells that can be recalled upon re-exposure to the same pathogen [25]. Although the development of an effector CTL response should result in clearance of $\mathrm{HCV}$, in most instances $\mathrm{HCV}$ manages to escape immune control and becomes persistent [25]. If antigen stimulation remains high, the result can be exhaustion, characterized by an inability to develop and mount a functional CTL response [25]. However, the mechanism contributing to $\mathrm{HCV}$-specific $\mathrm{CD} 8^{+} \mathrm{T}$-cell failure and the resulting persistence of HCV infection is still poorly understood. Complex molecular pathways, including transcriptional differences, direct the differentiation of $\mathrm{CD}^{+} \mathrm{T}$ cells into memory or exhausted $\mathrm{T}$ cells during $\mathrm{HCV}$ infection [26]. Memory T cells during spontaneously resolved HCV infection share co-regulated T cell identity genes while exhausted $\mathrm{T}$ cells share different co-regulated $\mathrm{T}$ cell identity genes, distinguishing the two populations [26]. The cytokines secreted by $\mathrm{T}$ cells during viral replication influence the final outcome of $\mathrm{HCV}$ infection. The role of $\mathrm{CD}^{+}$have also been explored during $\mathrm{HCV}$ infection suggesting the presence of $\mathrm{HCV}$-specific $\mathrm{CD}^{+} \mathrm{T}$ cell responses to be common in spontaneously resolved $\mathrm{HCV}$ infection [27-30]. A more recent study found the majority of peripheral HCV-specific CD4 ${ }^{+} \mathrm{T}$ cells in patients with self-limiting HCV infection had an effector phenotype $\left(\mathrm{CD} 4{ }^{+} \mathrm{CD} 25^{\text {high }} \mathrm{CD} 134^{+} \mathrm{CD} 39^{-}\right)$ with high IFN- $\gamma$ production, while the $\mathrm{HCV}$-specific $\mathrm{CD} 4^{+} \mathrm{T}$ cells from patients who progressed to a chronic HCV infection were dominated by a regulatory phenotype $\left(\mathrm{CD} 4{ }^{+} \mathrm{CD} 25^{\text {high }} \mathrm{CD} 134^{+} \mathrm{CD} 39^{+}\right)$ and high IL-10 production [31]. It has also been shown that the majority of liver-infiltrating T cells in chronic HCV infection are Type 1 Helper $\mathrm{T}\left(\mathrm{T}_{\mathrm{h}} 1\right)$ cells able to secrete IFN- $\gamma$, but unable to secrete IL-4 or IL-5 [32].

As seen in other chronic viral infections [33-37], persistent infection with HCV results in T cell exhaustion [38]. HCV-related exhaustion leads to weak or absent HCV-specific antiviral T cell responses. T cell exhaustion develops in a step-wise and progressive manner, varies in severity, and results in blunted virus-specific immunity [39]. These include an impaired ability to respond to viral peptide and to mitogen. Exhausted T cells have impaired proliferation abilities and reduced secretion of antiviral cytokines including IL-2 [40], IFN- $\gamma$ [37,41], IL-21 [42] and TNF- $\alpha$ [41,43]. These T cells also express high levels of exhaustion markers, PD-1 [44-47], TIM-3 [48-52] and CTLA-4 [53,54] and low levels of memory markers such as interleukin 7 receptor (CD127) [46,55-57] and Bcl-2 [58]. Co-expression of PD-1 with 2B4, CD160 and KLRG1 has been shown on exhausted T cells during HCV infection [59]. Additionally, murine models have demonstrated signaling through TIGIT is critical for maintaining chronic exhaustion during prolonged viral infection [60]. The presence of TIGIT has been shown on exhausted $\mathrm{T}$ cells during viral infection and its expression positively correlates with disease progression [61]. In chronic HCV infection, this exhausted immune phenotype is present and presumed to be the reason for failure to clear viral infection [62]. In this review, we provide background on HCV immune dysfunction and review literature exploring the restoration of $\mathrm{HCV}$-specific immune responses with antiviral therapy, both IFN-based and more recent DAA therapies.

\subsection{Treatment of HCV Infection}

The main goal of HCV therapy is to achieve a sustained virological response (SVR), defined as the absence of detectable HCV RNA in the serum 3 months following the completion of therapy [63]. Traditionally, HCV was treated with pegylated-interferon (PEG-IFN) in combination with ribavirin, a nucleoside analogue, demonstrating SVR rates between 30\%-60\% among chronically infected patients depending on the HCV genotype $[64,65]$. The introduction of direct-acting antiviral (DAA) therapy in 2011, with the approval of two protease inhibitors, provided promising improvement in SVR rates for patients infected with genotype 1 [66-69]. The second wave of DAAs, covering more drug classes, resulted in a new IFN-free standard of care for chronic HCV [70]. With current DAA therapies, SVR is achieved in $>95 \%$ of patients, a considerable improvement from the success rates seen with IFN therapy [1]. These IFN-free regimens offer significantly higher efficacy and tolerability, even in previously challenging populations [71]. Unfortunately, patients continue to clear the virus without sterilizing protection against reinfection [72]. Lack of sterilizing protective immunity means reinfection 
is common, especially among populations with ongoing risk exposures [73-76]. The risk of reinfection after effective treatment is reported as 2-6/100 person years among people who inject drugs (PWID) and 10-15/100 person years among human immunodeficiency virus (HIV)-infected men who have sex with men (MSM) [77]. Even these estimates may be low, as they rely on the diagnosis of reinfection, which may include a population more connected to care. Clinical trials have investigated the use of 6 or 8 weeks of DAA regimens during acute HCV infection [78-81]. Six weeks of treatment with sofosbuvir and ribavirin demonstrated high safety and tolerability, but efficacy was suboptimal with common post-treatment relapse (9/19 participants) [80]. More recent studies investigating the use of ledipasvir and sofosbuvir in acute $\mathrm{HCV}$ infection documented high tolerability as well as efficacy $[78,79,81]$. These trials make a strong case for short-duration treatment of acute HCV infection with potent combination DAA therapy to prevent spread in high-risk populations. However, questions remain about whether timing of treatment and earlier viral clearance could promote protective immunity upon reinfection.

\subsection{Evidence of Protective Immunity in HCV Infection}

The correlates of protective immunity against HCV infection are not well elucidated. A rapid generation of neutralizing antibodies (nAbs) in the acute phase of infection is associated with spontaneous clearance of infection [82,83], but viral control has also been detected in the absence of high $\mathrm{nAb}$ responses [84]. Furthermore, HCV RNA persists in chronic infection with the presence of nAbs [85]. These nAbs are thought to be ineffective as the virus employs effective evasion strategies to escape host immunity. HCV's RNA Polymerase (NS5B) introduces frequent point mutations generating diversity in nucleotide sequences within quasispecies of a single infected host [86,87]. Glycosylation sites present on envelope glycoproteins (E1 and E2) form a glycan shield to protect functional domains and, consequently, limit access of epitopes to nAbs [86]. Furthermore, interfering Abs and the ability of the virus to disseminate cell-to-cell hinders the action of nAbs [86,88]. Together, these results suggest that naturally-produced antibodies alone do not provide protective immunity.

Despite a lack of sterilizing immunity, studies in chimpanzees and humans have demonstrated evidence of protective immunity following spontaneous clearance of HCV [24,89,90]. Reinfection of chimpanzees with HCV demonstrates lower peak viremia and more efficient resolution of infection compared to primary infection [24]. Antibody-mediated depletion of memory $\mathrm{CD} 8^{+} \mathrm{T}$ cells before a third infection resulted in an established infection, confirming the role of $\mathrm{CD}^{+} \mathrm{T}$ cells in clearance of reinfection [24]. Among people who inject drugs (PWID), the duration and maximum level of viremia during reinfection were decreased, compared with their primary infection [89]. The demonstration that spontaneous clearance without the development of $\mathrm{T}$ cell exhaustion leads to levels of protective immunity suggests optimizing the timing of treatment to maximize the reversal of or even prevent $\mathrm{T}$ cell exhaustion could be valuable [90].

\subsection{Reversing Immune Dysfunction with Blockade of Exhaustion Markers}

There has been considerable interest in avoiding and/or reversing immune exhaustion to encourage improved outcomes for patients with HCV infection. The blockade of PD-1 has been evaluated in vitro and shown to increase the response of peripheral blood-derived $\mathrm{HCV}$-specific $\mathrm{CD} 8^{+} \mathrm{T}$ cells to $\mathrm{HCV}$ peptide stimulation $[41,46]$. However, PD-1 blockade failed to restore the function of HCV-specific $\mathrm{CD}^{+} \mathrm{T}$ cells that were isolated from liver biopsies [91]. Subsequent studies demonstrated that the restoration of intrahepatic $\mathrm{T}$ cell function required simultaneous blockade of several inhibitory molecules including CTLA-4 and TIM-3 [53,92].

Anti-PD-1 antibodies have been used to block PD-1 signaling in both HCV-infected chimpanzees [93] and in human patients with chronic HCV infection [94]. Fuller et al. showed an increase in $\mathrm{HCV}$-specific $\mathrm{CD} 8^{+} \mathrm{T}$ cell responses and a significant but transient reduction in $\mathrm{HCV}$ viremia in one of three chimpanzees [93]. This animal had the strongest and broadest CD4 ${ }^{+}$and $\mathrm{CD} 8^{+}$ $\mathrm{T}$ cell response prior to development of chronic infection, which suggests that PD-1 blockade alone is not sufficient to achieve viral clearance [93]. Gardiner et al. demonstrated partial success of PD-1 
blockade in a human population [94]. Five patients who received anti-PD-1 antibodies and one placebo patient demonstrated a reduction in HCV RNA $\geq 0.5 \log 10 \mathrm{IU} / \mathrm{mL}$ on at least 2 consecutive visits [94]. Three patients who received the PD- 1 blockade achieved a $>4 \log 10$ reduction. Two patients who received the PD-1 blockade achieved HCV RNA below the lower limit of quantitation, one of which remained RNA-undetectable one year after the study was completed [94]. The observed reductions in HCV replication persisted for more than eight weeks in the majority of patients demonstrating continued reversal of exhaustion [94]. Besides exhaustion marker blockade, researchers have also explored the potential to leverage $\mathrm{HCV}$ treatment to restore immune function.

\section{Improved Immune Restoration in Acute vs. Chronic IFN- $\alpha$ Treatment}

Spontaneous clearance of acute HCV infection is characterized by the presence of HCV-specific $\mathrm{CD}^{+} \mathrm{T}$ cells expressing memory marker IL-7R $\alpha$ (CD127) and anti-apoptotic marker Bcl-2 with strong functional responses measured by cytokine secretion [95]. Spontaneous resolution correlates with early development of IFN- $\gamma$ - and IL-2-producing and $\mathrm{CD} 107 \mathrm{a}^{+}$virus-specific $\mathrm{CD} 8^{+} \mathrm{T}$ cells [95]. A body of literature suggests that this phenotype can be preserved and/or re-established when IFN- $\alpha$ therapy is administered during acute HCV infection, but not during chronic HCV infection [95-97]. Several studies have investigated immune restoration following IFN- $\alpha$ therapy, the previous standard of care for HCV infection. Vertuani et al. found that following IFN- $\alpha$ therapy with or without ribavirin, patients who successfully cleared chronic $\mathrm{HCV}$ infection exhibited significantly stronger $\mathrm{HCV}$-specific $\mathrm{CD}^{+}$responses than the untreated patients with chronic $\mathrm{HCV}$ infection [98]. The majority of treated patients showed $\mathrm{CD} 8^{+}$responses to at least $3 \mathrm{HCV}$ specific epitopes, demonstrating a $\mathrm{CD} 8^{+}$ response directed against more epitopes compared to the untreated group [98]. Morishima et al. also demonstrated that $\mathrm{HCV}$-specific cytolytic responses measured by chromium release limiting dilution assay are found more commonly with IFN treatment (with or without ribavirin)-induced control of viremia measured 6 months post-treatment compared to individuals chronically infected with HCV [99]. Tatsumi et al. looked at the frequencies of HCV-specific $C D 8^{+} \mathrm{T}$ cells following combination therapy of PEG-IFN- $\alpha$ with ribavirin in patients with chronic HCV infection. Their results demonstrated a significant increase of $\mathrm{HCV}$-specific $\mathrm{CD} 8^{+} \mathrm{T}$ cells at 4 weeks after the initiation of treatment compared to frequencies measured in the same patient group pre-treatment [100]. This increase may be associated with elimination of HCV [100]. Furthermore, they suggest that specific reactivity to Core and NS3 protein-derived peptides may predict clearance of the virus with IFN treatment [100]. Kamal et al. focused on HCV-specific $C D 4^{+} \mathrm{T}_{\mathrm{h}} 1$ responses in patients chronically infected with HCV [101]. This study found that patients who achieved SVR following PEG-IFN- $\alpha$ therapy with or without ribavirin, maintained multispecific $\mathrm{HCV}$-specific $\mathrm{CD} 4^{+} \mathrm{T}$-cell responses with enhanced IFN- $\gamma$ production [101]. In contrast, the $\mathrm{HCV}$-specific $\mathrm{CD} 4^{+} \mathrm{T}_{\mathrm{h}} 1$ responses in patients who relapsed or only partially responded to therapy waned or were lost [101].

Interestingly, Caetano et al. reported that treatment-naïve chronically HCV-infected patients who would eventually achieve a sustained response to IFN therapy showed significantly stronger $\mathrm{HCV}$ specific $\mathrm{CD} 8^{+} \mathrm{T}$ cell response than non-responders prior to therapy [102]. In responder patients, terminally differentiated effector cells increased more rapidly, and their frequency was always higher than in non-responder patients. Sustained-responder patients also showed a higher frequency of $\mathrm{HCV}$-specific $\mathrm{CD}^{+} \mathrm{T}$ cells producing cytotoxic factors including perforin and granzyme B involved in cell death by lysis and apoptosis.

Badr et al. analyzed a cohort of patients who resolved acute infection following early treatment and documented the phenotype and function of HCV tetramer-specific cells prior to, during and up to 1 year following completion of PEG-IFN- $\alpha$ antiviral therapy with no ribavirin [95]. Early IFN therapy reconstituted a $\mathrm{T}$ cell memory response with the same phenotypic and functional characteristics as memory T cells induced following spontaneous clearance [95]. Upregulation of CD127 and Bcl-2 upon viral elimination was documented, and remained detectable 58 weeks post-treatment. PD-1 expression on HCV-specific T cells was downregulated in all patients upon viral clearance [95]. Overall 
expression of CD127, Bcl-2 and PD-1 was not affected in total CD8 ${ }^{+} \mathrm{T}$ cells and control staining using cytomegalovirus (CMV) and flu tetramers demonstrating the phenotypic observation was exclusive to HCV-specific T cells [95].

Abdel-Hakeem et al. compared reconstitution in early versus late IFN- $\alpha$ therapy without ribavirin [96]. $\mathrm{CD} 8^{+} \mathrm{T}$ cell proliferative responses were higher in patients treated during acute versus chronic HCV infection, and did not differ significantly when acutely treated patients were compared to those who spontaneously cleared HCV [96]. HCV-specific IFN- $\gamma$ producing responses by $\mathrm{CD} 4^{+}$ and $\mathrm{CD} 8^{+} \mathrm{T}$ cells were higher in the acute treatment group compared to patients who were treated in chronic HCV infection and achieved SVR [96]. Missale et al. compared HCV-specific CD8 ${ }^{+}$T cell functional restoration as evidenced by IFN- $\gamma$ analysis directly ex vivo after PEG-IFN- $\alpha$ treatment with or without ribavirin in individuals with acute and chronic HCV infection [97]. Mean frequency of IFN- $\gamma$-positive HCV-specific CD8 ${ }^{+} \mathrm{T}$ cells was higher among acutely treated individuals compared to those treated in chronic HCV infection [97]. In contrast, the frequency of IL-2 positive HCV-specific $\mathrm{CD}^{+} \mathrm{T}$ cells was similar in individuals treated during acute HCV infection, individuals treated during chronic HCV infection and spontaneously-resolving groups [97]. IFN- $\gamma$ production by HCV-specific $\mathrm{CD}^{+} \mathrm{T}$ cells after in vitro expansion, proliferative ability and cytotoxic $\mathrm{T}$ cell function was stronger in patients with an acute HCV infection compared to those with a chronic HCV infection and more closely resembled self-resolvers [97]. Proliferative capacity was also measured during acute phase of infection and after treatment. This demonstrated restoration of proliferative capacity post treatment in 3 of 4 patients tested [97]. These results are in line with Abdel-Hakeem et al. [96], and suggest an incomplete functional restoration following treatment of acute $\mathrm{HCV}$ infection despite improvement with respect to treatment of chronic HCV infection.

Collectively, these data suggest that IFN-induced SVR leads to partial, but incomplete restoration of HCV-specific immune responses. Restoration is more marked when HCV is treated during the acute phase of infection, possibly because treatment occurs before the development of exhaustion. One confounding factor is the effect of IFN- $\alpha$ itself as it has inhibitory effects on lymphocytes, including both $\mathrm{CD}^{+}$and $\mathrm{CD} 8^{+} \mathrm{T}$ cells, rendering it difficult to definitively determine if the IFN- $\alpha$ therapy or viral exposure is responsible for changes in phenotype $[103,104]$. IFN- $\alpha$ blocks S-phase entry of stimulated $\mathrm{T}$ lymphocytes inhibiting proliferation [103]. IFN production can be induced endogenously by poly(I . C), a mismatched double-stranded RNA. Virus-induced suppression of proliferation can be replicated by contact with the poly $(\mathrm{I} \cdot \mathrm{C})$, while no poly $(\mathrm{I} \cdot \mathrm{C})$-induced impairment in proliferation can be seen in cells lacking IFN- $\alpha / \beta$ receptors [105]. The introduction of highly effective IFN-free second-generation DAA treatments could help clarify the question of whether IFN-based therapy itself or long-lasting exposure to ongoing viral replication mediates $\mathrm{T}$ cell impairment.

\section{Unclear Outcomes for Immune Restoration following Direct-Acting Antiviral (DAA) Therapy}

With the introduction of DAA therapies in 2011, we can now study immune restoration in the absence of IFN. DAA therapy has been shown to restore $\mathrm{HCV}$-specific $\mathrm{CD} 8^{+} \mathrm{T}$ cells in patients with chronic HCV infection [106]. Martin et al.'s cohort of individuals with chronic HCV infection was treated with a combination of faldaprevir and deleobuvir with or without ribavirin [106]. Significant increases in the frequency of $\mathrm{HCV}$-specific $\mathrm{CD} 8^{+} \mathrm{T}$ cells were seen at follow-up compared to baseline after in vitro expansion in the majority of patients that achieved SVR12 [106]. Successful DAA treatment was associated with an increase in CD127 expression on initially CD127-negative HCV-specific $\mathrm{CD}^{+} \mathrm{T}$ cells in two patients [106]. Furthermore, a decrease of mean PD-1 expression on HCV-specific $\mathrm{CD}^{+} \mathrm{T}$ cells from $33.9 \%$ at baseline to $18.0 \%$ at follow up was documented [106]. Burchill et al. documented a reconstitution of the $\mathrm{CD}^{+} \mathrm{T}$ cell compartment and partial reversal in exhaustion markers on HCV-specific T cells following DAA treatment in patients with chronic $\mathrm{HCV}$ infection [107]. This restoration was apparent through an increase in $\mathrm{CD} 4^{+} \mathrm{T}$ cell numbers and a temporal increase in the proliferative response to T cell receptor (TCR) stimulation [107]. A reduction in expression of co-inhibitory molecule, $\mathrm{T}$ cell immunoreceptor with immunoglobulin and 
immunoreceptor tyrosine-based inhibition motif domains (TIGIT) on all $\mathrm{T}$ lymphocytes was also documented [107]. A partial reversal in exhaustion phenotype was found in $\mathrm{HCV}$-specific $\mathrm{CD}^{+} \mathrm{T}$ cells with a reduction in PD-1 expression, but no increase in frequency of circulating HCV-specific $\mathrm{CD}^{+} \mathrm{T}$ cells [107]. The percentage of NK cells expressing TIM-3 was reduced following DAA therapy, and circulating NK cells shifted towards a differentiated, more functionally active population shown through reduction in T-bet and increase in Eomes, two T-box transcription factors [107].

A restoration in T-cell activation was documented in a recent study by Emmanuel et al. among $\mathrm{HCV}$-monoinfected and HIV/HCV co-infected patients treated with DAA therapy during chronic HCV infection [108]. The study found increasing recovery in T-cell activation during DAA therapy and post-SVR [108]. Before DAA therapy, HCV-monoinfected patients had higher $\mathrm{CD} 4^{+}$and $\mathrm{CD} 4^{+}: \mathrm{CD} 8^{+}$ T-cell ratio [108]. An observed decrease in activated $\mathrm{CD} 4^{+}$and $\mathrm{CD} 8^{+} \mathrm{T}$ cells in both monoinfected and coinfected patients from pretreatment to post-SVR suggests clearance of HCV normalizes activated T-cell levels [108].

Wieland et al. investigated the differentiation and outcome of HCV-specific CD8 ${ }^{+} \mathrm{T}$ cells after DAA therapy [109]. HCV-specific $\mathrm{CD}^{+} \mathrm{T}$ cell populations from patients chronically infected with $\mathrm{HCV}$ displayed a heterogeneous phenotype that included $\mathrm{CD} 127^{+} \mathrm{PD}^{+}, \mathrm{CD} 127-\mathrm{PD} 1^{\mathrm{lo}}$ and CD127-PD1 ${ }^{\text {hi }}$ subsets [109]. This study also examined the expression of T cell factor 1 (TCF1), which is a transcription factor required for the differentiation and persistence of memory $\mathrm{CD} 8^{+} \mathrm{T}$ cells. A larger proportion of $\mathrm{CD} 127^{+} \mathrm{PD} 1^{+} \mathrm{HCV}$-specific T cells expressed TCF1 compared to the other subsets. These $\mathrm{TCF} 1^{+} \mathrm{CD} 127^{+} \mathrm{PD} 1^{+} \mathrm{T}$ cells were maintained during and after DAA-induced $\mathrm{HCV}$ elimination and showed memory-like characteristic including survival in the absence of HCV antigen and recall proliferation after HCV viral relapse. Peptide-expanded HCV-specific CD8 ${ }^{+} \mathrm{T}$ cells derived from patients at the completion of DAA therapy exhibited increased IFN- $\gamma$ production compared to baseline suggesting some immune restoration in patients following DAA treatment of chronic HCV infection [109].

However, in a study by Zhang et al. the authors found no functional immune reconstitution of HCV-specific T cells after DAA treatment in patients chronically infected with HCV [110]. Although DAA treatment of chronic HCV infection led to SVR in all patients, immune reconstitution was not documented [110]. This cohort was composed of both HCV-1b and HCV-2a chronically infected patients who were given 12 or 24 weeks of combination DAA therapies [110]. Successful treatment did not improve antigen-specific $\mathrm{CD}^{+} \mathrm{T}$ cell IFN- $\gamma$ production with all patient groups changing between time points presenting no apparent trend [110]. Phenotyping experiments did not reveal any significant differences in PD- 1 expression before and after treatment for both $\mathrm{CD} 4^{+}$and $\mathrm{CD} 8^{+} \mathrm{T}$ cells [110]. The reasons for these differences in results compared to the earlier DAA studies in patients chronically infected with HCV is not clear and suggests that larger studies may be warranted.

Some indirect evidence of immune recovery after HCV clearance was demonstrated in a cohort of patients with chronic HCV-induced cryoglobulinemia vasculitis who were treated with DAA therapy. Successful HCV clearance with DAA therapy has been shown to reverse disturbances in peripheral B- and T-cell populations [111]. In HCV-associated cryoglobulinemia vasculitis, Follicular Helper T cells $\left(\mathrm{T}_{\mathrm{FH}}\right)$ expansion has been associated with $\mathrm{T}_{\mathrm{h}} 1$ and $\mathrm{T}$ Helper 17 Cells $\left(\mathrm{T}_{\mathrm{h}} 17\right)$ polarization, and expansion of $\mathrm{IgM}^{+} \mathrm{CD} 21^{-/ \text {low }}$ memory $\mathrm{B}$ cells and low levels of $\mathrm{T}_{\text {reg }}$ cells [111]. DAA therapy improves irregularities in B-cell homeostasis, with a decreased percentage of autoreactive memory B cells and cryoglobulin levels post therapy [111]. Furthermore, successful anti-HCV therapy restores T-cell homeostasis by reestablishing $T_{h} 1 / T_{h} 17$ balance and improving $T$ cell activation [111].

During an infection with $\mathrm{HCV}$ there is a marked increase in intrahepatic and peripheral IFN-stimulating genes (ISGs) [112-114]. The majority of ISGs have antiviral properties, but upregulation during a chronic infection with HCV is ineffective at clearing the virus [112-114]. The inability of the host to clear HCV with increased ISG expression suggest an exhausted immune phenotype characterized by a refractory state of IFN-signaling [112]. Holmes et al. investigated changes in innate immune response during and after DAA therapy administered during chronic $\mathrm{HCV}$ infection [115]. 
ISG expression was found to be downregulated at week 2 and 4 of DAA treatment, but recovered by the end of treatment to a level below that observed at baseline [115]. ISGs quantified at SVR showed levels similar to treatment week 2 [115]. This second downregulation of ISG following DAA treatment, suggests a reversal of the exhausted ISG phenotype [115]. NK cell activity, a key component of the innate immune response, is reduced in individuals chronically infected with HCV [116]. Corado et al. documented that spontaneous NK cytotoxicity was four-fold lower in patients chronically infected with HCV than in healthy donor demonstrating a significant functional impairment [116]. There are two major populations of NK cells, CD $56^{\mathrm{dim}} \mathrm{NK}$ and CD56 ${ }^{\text {bright }} \mathrm{NK}$ [117-119]. CD56 $6^{\mathrm{dim}} \mathrm{NK}$ cells are more cytotoxic than CD56 $6^{\text {bright }} \mathrm{NK}$ cells [120], but produce significantly less IFN- $\gamma$ [121]. It was reported that a CD56 ${ }^{\text {dim }} \mathrm{NK}$ cell subset, but not a CD56 $6^{\text {bright }} \mathrm{NK}$ cell subset, showed significantly lower frequencies in patients with chronic HCV compared to healthy subjects [122]. DAA therapy in chronic HCV patients has been shown to improve NK activity by increasing the frequency of CD $56^{\mathrm{dim}} \mathrm{NK}$ cells at SVR24 [123]. It was also found that NK activity quantified by Chromium-50 release assay significantly improved at end of treatment versus prior to therapy $(p<0.01)$ and at follow up 24 weeks post treatment (SVR24) versus prior to treatment $(p<0.001)$ in 30 patients [123].

\section{Conclusions and Future Perspectives}

IFN-based treatment during acute HCV infection has demonstrated an improved likelihood of immune restoration compared to patients treated in chronic HCV infection. Figure 1 shows an inverse relationship between the level of immune restoration and the duration of exposure to $\mathrm{HCV}$ antigen. DAA treatment has led to some level of immune restoration when administered to patients chronically infected with $\mathrm{HCV}$, but results are variable and require further investigation (Figure 1). Reversal of HCV-specific immune exhaustion results in treated patients acquiring an immunological phenotype similar to spontaneous clearers. Combining these results, there is reason to believe that DAA treatments will outperform IFN therapy in their capacity to rescue exhausted T cells upon HCV clearance during acute infection.

Complicated molecular pathways determine the differentiation of $\mathrm{CD}^{+} \mathrm{T}$ cells into memory or exhausted T cells during HCV infection [26]. In a prospective study, the transcriptional profiles of $\mathrm{HCV}$-specific $\mathrm{CD}^{+} \mathrm{T}$ cells from $\mathrm{HCV}$ infected patients progressing to persistent infection and patients spontaneously resolving HCV infection were compared during the acute phase of infection [26]. Dysregulation of metabolic processes during acute infection was observed in patients who progressed to persistent infection [26]. This dysregulation was linked to changes in gene expression related to cellular pathways including nucleosomal regulation of transcription, $\mathrm{T}$ cell differentiation, and the inflammatory response [26]. These changes in HCV-specific $\mathrm{CD}^{+} \mathrm{T}$ cell transcription came before the establishment of $\mathrm{T}$ cell exhaustion, suggesting it as a target the origins of $\mathrm{T}$ cell exhaustion in chronic HCV infection [26]. Further research and understanding in this field, may help direct treatment to improve restoration and lower dysfunction.

It is difficult to determine if this reconstitution is the cause or effect of enhanced viral clearance. It is hypothesized that it is the consequence of clearance, as T cells are being further exhausted by continued antigen exposure. Large studies to track reinfection following DAA treatment at different stages of infection are necessary to see the outcome of protective immunity. The studies included in this review typically utilize peripheral immune cells and it is not fully understood how the function of peripheral and liver-infiltrating immune cells parallels each other. Recent investigation suggests HCV-specific T cell responses in the periphery do not reflect those in the liver [124]. 


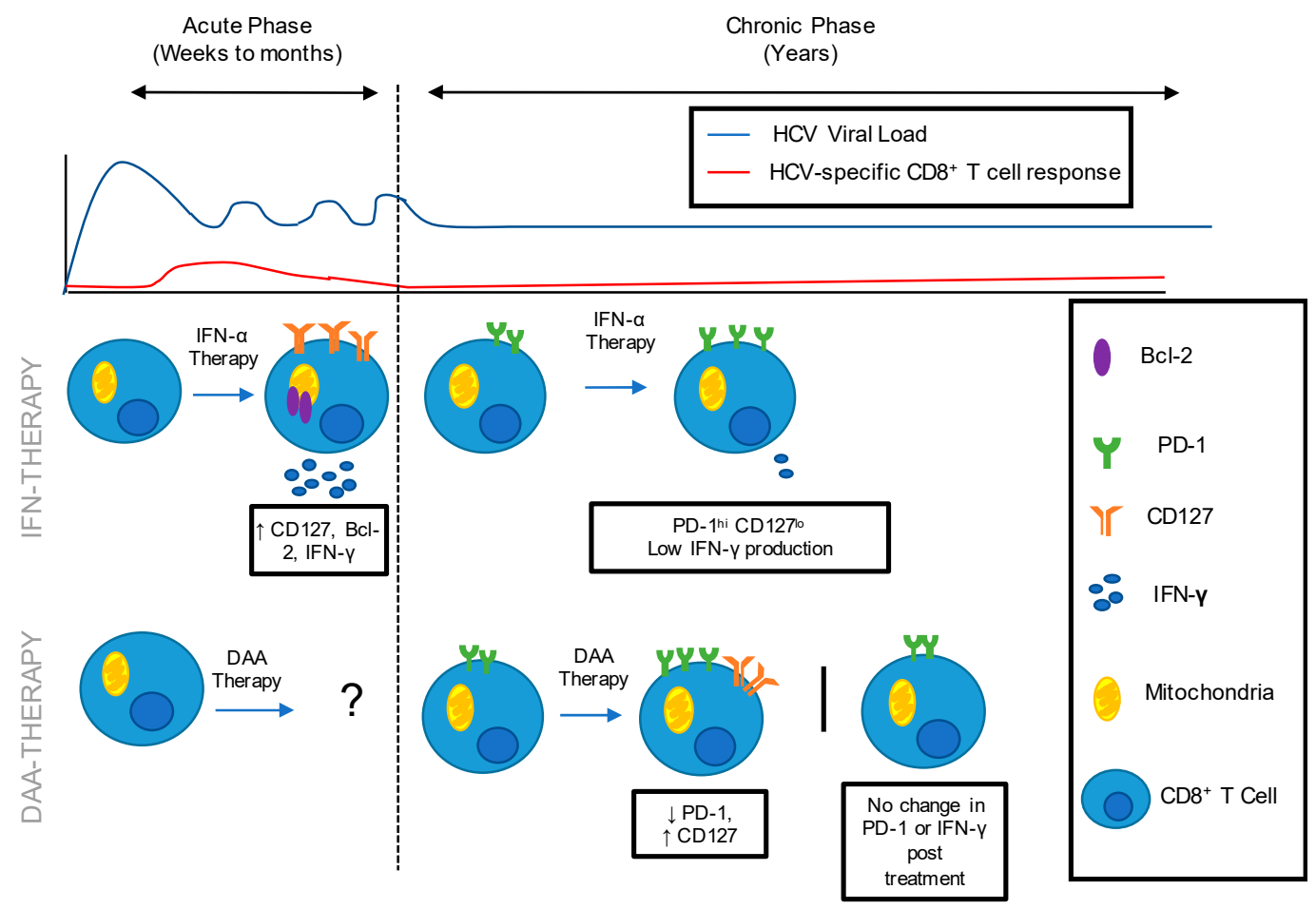

Figure 1. HCV-specific Immune Restoration following IFN and DAA therapy administered during the acute and chronic phase of HCV infection. HCV is characterized by an acute phase of infection in which the immune response is unable to control HCV replication, leading to chronicity in the majority of patients. Following IFN- $\alpha$ therapy administered during acute $\mathrm{HCV}$ infection: $\mathrm{CD}^{+} \mathrm{T}$ cell populations expressed low levels of exhaustion marker, PD-1 and increased levels of memory marker CD127, anti-apoptotic marker Bcl- 2 and IFN- $\gamma$ production. Following IFN- $\alpha$ therapy administered during chronic HCV infection: CD8+ T cell populations expressed high level PD-1 and low level of CD127 and IFN- $\gamma$ production. Immune restoration following DAA therapy administered during acute HCV infection has not been documented in the literature. Following DAA therapy administered during chronic HCV infection: Literature demonstrates varying results. Decreased PD-1 and increased CD127 has been reported, while no change in PD-1 expression post-treatment has also been reported.

Presently, DAA treatment is generally initiated during chronic HCV infection to avoid treating patients who may spontaneously clear the infection without treatment. Based on current research, we identify the need to investigate immune restoration following early treatment of HCV infection with current DAAs. We hypothesize that DAAs administered during acute infection may prevent progressive $\mathrm{T}$ cell exhaustion characteristic of chronic HCV infection, leading to enhanced $\mathrm{T}$ cell memory and improved protection against progression to chronicity upon subsequent $\mathrm{HCV}$ reinfection. Ongoing clinical trials testing the efficacy of DAA treatment for recently-acquired HCV infection, including the REACT Trial (Randomized Study of Interferon-free Treatment for Recently Acquired Hepatitis C in People Who Inject Drugs and People with HIV Coinfection, (https:/clinicaltrials.gov/ ct2/show/NCT02625909) may be leveraged to explore immune restoration following DAA therapy administered in early HCV infections. The REACT trial includes a long follow-up period to monitor cases of reinfection among this population. Data and samples generated from this trial may be used to study HCV-specific immune restoration following therapy during acute $\mathrm{HCV}$ infection and investigate evidence of protection against progression to chronicity after reinfection.

The potential for immune restoration with early treatment may have additional clinical benefits, including a reduced risk of hepatocellular carcinoma (HCC) development. The risk of HCC after DAA-induced SVR is unclear. A recent study found that among patients treated with DAA, SVR was associated with a reduction in the risk of HCC compared to patients who did not achieve SVR [125]. As the majority of infected individuals do not develop specific symptoms, improved 
screening methods to identify unknowingly infected individuals is necessary. Future findings could provide the foundation for informing treatment guidelines for early HCV infection and improve our understanding of $\mathrm{HCV}$-induced $\mathrm{T}$ cell exhaustion while further elucidating the factors associated with protective immunity among these patients. While studies continue to address the barriers related to the development of an $\mathrm{HCV}$ vaccine, early treatment may be used to rescue immune responses and reduce reinfection rates.

Author Contributions: J.L.C., J.J.F. and S.A.M. participated in the writing and editing of this review.

Funding: This review received no external funding.

Conflicts of Interest: J.1.C. and S.A.M. declare no conflict of interest. J.J.F. has received honoraria for scientific consulting from AbbVie, Gilead, and Merck, and his institution has received research support from AbbVie, Gilead, Janssen, Merck.

\section{References}

1. WHO. Global Hepatitis Report 2017; WHO: Geneva, Switzerland, 2017.

2. Hoofnagle, J.H. Course and outcome of hepatitis C. Hepatology 2002, 36, S21-S29. [CrossRef] [PubMed]

3. Blackard, J.T.; Shata, M.T.; Shire, N.J.; Sherman, K.E. Acute hepatitis C virus infection: A chronic problem. Hepatology 2008, 47, 321-331. [CrossRef] [PubMed]

4. Islam, N.; Krajden, M.; Shoveller, J.; Gustafson, P.; Gilbert, M.; Wong, J.; Tyndall, M.W.; Janjua, N.Z.; BC-HTC Team. Hepatitis C cross-genotype immunity and implications for vaccine development. Sci. Rep. 2017, 7 , 12326. [CrossRef]

5. Thomas, D.L.; Thio, C.L.; Martin, M.P.; Qi, Y.; Ge, D.; O’Huigin, C.; Kidd, J.; Kidd, K.; Khakoo, S.I.; Alexander, G.; et al. Genetic variation in IL28B and spontaneous clearance of hepatitis C virus. Nature 2009, 461, 798-801. [CrossRef] [PubMed]

6. Grebely, J.; Page, K.; Sacks-Davis, R.; van der Loeff, M.S.; Rice, T.M.; Bruneau, J.; Morris, M.D.; Hajarizadeh, B.; Amin, J.; Cox, A.L.; et al. The effects of female sex, viral genotype, and IL28B genotype on spontaneous clearance of acute hepatitis C virus infection. Hepatology 2014, 59, 109-120. [CrossRef]

7. Rehermann, B. Hepatitis $\mathrm{C}$ virus versus innate and adaptive immune responses: $\mathrm{A}$ tale of coevolution and coexistence. J. Clin. Investig. 2009, 119, 1745-1754. [CrossRef]

8. Grebely, J.; Raffa, J.D.; Lai, C.; Krajden, M.; Conway, B.; Tyndall, M.W. Factors associated with spontaneous clearance of hepatitis $C$ virus among illicit drug users. Can. J. Gastroenterol. 2007, 21, 447-451. [CrossRef]

9. Bulteel, N.; Partha Sarathy, P.; Forrest, E.; Stanley, A.J.; Innes, H.; Mills, P.R.; Valerio, H.; Gunson, R.N.; Aitken, C.; Morris, J.; et al. Factors associated with spontaneous clearance of chronic hepatitis $C$ virus infection. J. Hepatol. 2016, 65, 266-272. [CrossRef]

10. Dutoit, V.; Ciuffreda, D.; Comte, D.; Gonvers, J.J.; Pantaleo, G. Differences in HCV-specific T cell responses between chronic HCV infection and HIV/HCV co-infection. Eur. J. Immunol. 2005, 35, 3493-3504. [CrossRef]

11. Shafran, S.D. HIV Coinfected Have Similar SVR Rates as HCV Monoinfected With DAAs: It's Time to End Segregation and Integrate HIV Patients Into HCV Trials. Clin. Infect. Dis. 2015, 61, 1127-1134. [CrossRef]

12. Kong, F.; Pan, Y.; Chi, X.; Wang, X.; Chen, L.; Lv, J.; Sun, H.; Wu, R.; Jin, J.; Yu, G.; et al. Factors associated with spontaneous clearance of hepatitis C virus in Chinese population. Biomed. Res. Int. 2014, 2014, 527030. [CrossRef] [PubMed]

13. Suppiah, V.; Moldovan, M.; Ahlenstiel, G.; Berg, T.; Weltman, M.; Abate, M.L.; Bassendine, M.; Spengler, U.; Dore, G.J.; Powell, E.; et al. IL28B is associated with response to chronic hepatitis C interferon-alpha and ribavirin therapy. Nat. Genet. 2009, 41, 1100-1104. [CrossRef] [PubMed]

14. Tanaka, Y.; Nishida, N.; Sugiyama, M.; Kurosaki, M.; Matsuura, K.; Sakamoto, N.; Nakagawa, M.; Korenaga, M.; Hino, K.; Hige, S.; et al. Genome-wide association of IL28B with response to pegylated interferon-alpha and ribavirin therapy for chronic hepatitis C. Nat. Genet. 2009, 41, 1105-1109. [CrossRef]

15. Shi, X.; Pan, Y.; Wang, M.; Wang, D.; Li, W.; Jiang, T.; Zhang, P.; Chi, X.; Jiang, Y.; Gao, Y.; et al. IL28B genetic variation is associated with spontaneous clearance of hepatitis $C$ virus, treatment response, serum IL-28B levels in Chinese population. PLoS ONE 2012, 7, e37054. [CrossRef] [PubMed]

16. Rajeevan, H.; Soundararajan, U.; Kidd, J.; Pakstis, A.; Kidd, K. ALFRED: An allele frequency resource for research and teaching. Nucleic Acids Res. 2012, D1010-D1015. [CrossRef] [PubMed] 
17. Muir, A.J.; Hu, K.Q.; Gordon, S.C.; Koury, K.; Boparai, N.; Noviello, S.; Albrecht, J.K.; Sulkowski, M.S.; McCone, J. Hepatitis C treatment among racial and ethnic groups in the IDEAL trial. J. Viral Hepat. 2011, 18, e134-e143. [CrossRef] [PubMed]

18. Balagopal, A.; Thomas, D.L.; Thio, C.L. IL28B and the control of hepatitis C virus infection. Gastroenterology 2010, 139, 1865-1876. [CrossRef] [PubMed]

19. Alter, M.J.; Margolis, H.S.; Krawczynski, K.; Judson, F.N.; Mares, A.; Alexander, W.J.; Hu, P.Y.; Miller, J.K.; Gerber, M.A.; Sampliner, R.E. The natural history of community-acquired hepatitis C in the United States. The Sentinel Counties Chronic non-A, non-B Hepatitis Study Team. N. Engl. J. Med. 1992, 327, 1899-1905. [CrossRef]

20. Ahlenstiel, G. The natural killer cell response to HCV infection. Immune. Netw. 2013, 13, 168-176. [CrossRef]

21. Yoon, J.C.; Lim, J.B.; Park, J.H.; Lee, J.M. Cell-to-cell contact with hepatitis C virus-infected cells reduces functional capacity of natural killer cells. J. Virol. 2011, 85, 12557-12569. [CrossRef]

22. Holder, K.A.; Stapleton, S.N.; Gallant, M.E.; Russell, R.S.; Grant, M.D. Hepatitis C virus-infected cells downregulate NKp30 and inhibit ex vivo NK cell functions. J. Immunol. 2013, 191, 3308-3318. [CrossRef]

23. Saha, B.; Kodys, K.; Szabo, G. Hepatitis C Virus-Induced Monocyte Differentiation Into Polarized M2 Macrophages Promotes Stellate Cell Activation via TGF- $\beta$. Cell. Mol. Gastroenterol. Hepatol. 2016, 2, 302.e308-316.e308. [CrossRef]

24. Shoukry, N.H.; Grakoui, A.; Houghton, M.; Chien, D.Y.; Ghrayeb, J.; Reimann, K.A.; Walker, C.M. Memory CD8+ T cells are required for protection from persistent hepatitis C virus infection. J. Exp. Med. 2003, 197, 1645-1655. [CrossRef]

25. Williams, M.A.; Bevan, M.J. Effector and memory CTL differentiation. Annu. Rev. Immunol. 2007, 25, 171-192. [CrossRef]

26. Wolski, D.; Foote, P.K.; Chen, D.Y.; Lewis-Ximenez, L.L.; Fauvelle, C.; Aneja, J.; Walker, A.; Tonnerre, P.; Torres-Cornejo, A.; Kvistad, D.; et al. Early Transcriptional Divergence Marks Virus-Specific Primary Human CD8. Immunity 2017, 47, 648.e648-663.e648. [CrossRef] [PubMed]

27. Thimme, R.; Bukh, J.; Spangenberg, H.C.; Wieland, S.; Pemberton, J.; Steiger, C.; Govindarajan, S.; Purcell, R.H.; Chisari, F.V. Viral and immunological determinants of hepatitis $C$ virus clearance, persistence, and disease. Proc. Natl. Acad. Sci. USA 2002, 99, 15661-15668. [CrossRef]

28. Gerlach, J.T.; Diepolder, H.M.; Jung, M.C.; Gruener, N.H.; Schraut, W.W.; Zachoval, R.; Hoffmann, R.; Schirren, C.A.; Santantonio, T.; Pape, G.R. Recurrence of hepatitis C virus after loss of virus-specific CD4(+) T-cell response in acute hepatitis C. Gastroenterology 1999, 117, 933-941. [CrossRef]

29. Missale, G.; Bertoni, R.; Lamonaca, V.; Valli, A.; Massari, M.; Mori, C.; Rumi, M.G.; Houghton, M.; Fiaccadori, F.; Ferrari, C. Different clinical behaviors of acute hepatitis $C$ virus infection are associated with different vigor of the anti-viral cell-mediated immune response. J. Clin. Investig. 1996, 98, 706-714. [CrossRef]

30. Day, C.L.; Lauer, G.M.; Robbins, G.K.; McGovern, B.; Wurcel, A.G.; Gandhi, R.T.; Chung, R.T.; Walker, B.D. Broad specificity of virus-specific CD4+ T-helper-cell responses in resolved hepatitis C virus infection. J. Virol. 2002, 76, 12584-12595. [CrossRef]

31. Keoshkerian, E.; Hunter, M.; Cameron, B.; Nguyen, N.; Sugden, P.; Bull, R.; Zekry, A.; Maher, L.; Seddiki, N.; Zaunders, J.; et al. Hepatitis C-specific effector and regulatory CD4 T-cell responses are associated with the outcomes of primary infection. J. Viral Hepat. 2016, 23, 985-993. [CrossRef]

32. Bertoletti, A.; D’Elios, M.M.; Boni, C.; De Carli, M.; Zignego, A.L.; Durazzo, M.; Missale, G.; Penna, A.; Fiaccadori, F.; Del Prete, G.; et al. Different cytokine profiles of intraphepatic T cells in chronic hepatitis B and hepatitis C virus infections. Gastroenterology 1997, 112, 193-199. [CrossRef]

33. Day, C.L.; Kaufmann, D.E.; Kiepiela, P.; Brown, J.A.; Moodley, E.S.; Reddy, S.; Mackey, E.W.; Miller, J.D.; Leslie, A.J.; DePierres, C.; et al. PD-1 expression on HIV-specific T cells is associated with T-cell exhaustion and disease progression. Nature 2006, 443, 350-354. [CrossRef]

34. Moskophidis, D.; Lechner, F.; Pircher, H.; Zinkernagel, R.M. Virus persistence in acutely infected immunocompetent mice by exhaustion of antiviral cytotoxic effector T cells. Nature 1993, 362, 758-761. [CrossRef]

35. Fuller, M.J.; Khanolkar, A.; Tebo, A.E.; Zajac, A.J. Maintenance, loss, and resurgence of T cell responses during acute, protracted, and chronic viral infections. J. Immunol. 2004, 172, 4204-4214. [CrossRef] 
36. Gallimore, A.; Glithero, A.; Godkin, A.; Tissot, A.C.; Plückthun, A.; Elliott, T.; Hengartner, H.; Zinkernagel, R. Induction and exhaustion of lymphocytic choriomeningitis virus-specific cytotoxic T lymphocytes visualized using soluble tetrameric major histocompatibility complex class I-peptide complexes. J. Exp. Med. 1998, 187, 1383-1393. [CrossRef]

37. Wherry, E.J.; Blattman, J.N.; Murali-Krishna, K.; van der Most, R.; Ahmed, R. Viral persistence alters CD8 T-cell immunodominance and tissue distribution and results in distinct stages of functional impairment. J. Virol. 2003, 77, 4911-4927. [CrossRef] [PubMed]

38. Gruener, N.H.; Lechner, F.; Jung, M.C.; Diepolder, H.; Gerlach, T.; Lauer, G.; Walker, B.; Sullivan, J.; Phillips, R.; Pape, G.R.; et al. Sustained dysfunction of antiviral CD8+ T lymphocytes after infection with hepatitis C virus. J. Virol. 2001, 75, 5550-5558. [CrossRef]

39. Shin, E.C.; Sung, P.S.; Park, S.H. Immune responses and immunopathology in acute and chronic viral hepatitis. Nat. Rev. Immunol. 2016, 16, 509-523. [CrossRef]

40. Wherry, E.J.; Kurachi, M. Molecular and cellular insights into T cell exhaustion. Nat. Rev. Immunol. 2015, 15, 486-499. [CrossRef]

41. Penna, A.; Pilli, M.; Zerbini, A.; Orlandini, A.; Mezzadri, S.; Sacchelli, L.; Missale, G.; Ferrari, C. Dysfunction and functional restoration of $\mathrm{HCV}$-specific CD8 responses in chronic hepatitis $\mathrm{C}$ virus infection. Hepatology 2007, 45, 588-601. [CrossRef]

42. MacParland, S.A.; Fadel, S.M.; Mihajlovic, V.; Fawaz, A.; Kim, C.; Rahman, A.K.; Liu, J.; Kaul, R.; Kovacs, C.; Grebely, J.; et al. HCV Specific IL-21 Producing T Cells but Not IL-17A Producing T Cells Are Associated with HCV Viral Control in HIV/HCV Coinfection. PLoS ONE 2016, 11, e0154433. [CrossRef] [PubMed]

43. Crespo, J.; Sun, H.; Welling, T.H.; Tian, Z.; Zou, W. T cell anergy, exhaustion, senescence, and stemness in the tumor microenvironment. Curr. Opin. Immunol. 2013, 25, 214-221. [CrossRef] [PubMed]

44. Golden-Mason, L.; Palmer, B.; Klarquist, J.; Mengshol, J.A.; Castelblanco, N.; Rosen, H.R. Upregulation of PD-1 expression on circulating and intrahepatic hepatitis $\mathrm{C}$ virus-specific CD8+ $\mathrm{T}$ cells associated with reversible immune dysfunction. J. Virol 2007, 81, 9249-9258. [CrossRef] [PubMed]

45. Urbani, S.; Amadei, B.; Tola, D.; Massari, M.; Schivazappa, S.; Missale, G.; Ferrari, C. PD-1 expression in acute hepatitis $\mathrm{C}$ virus (HCV) infection is associated with $\mathrm{HCV}$-specific CD8 exhaustion. J. Virol. 2006, 80, 11398-11403. [CrossRef]

46. Radziewicz, H.; Ibegbu, C.C.; Fernandez, M.L.; Workowski, K.A.; Obideen, K.; Wehbi, M.; Hanson, H.L.; Steinberg, J.P.; Masopust, D.; Wherry, E.J.; et al. Liver-infiltrating lymphocytes in chronic human hepatitis C virus infection display an exhausted phenotype with high levels of PD-1 and low levels of CD127 expression. J. Virol. 2007, 81, 2545-2553. [CrossRef] [PubMed]

47. Barber, D.L.; Wherry, E.J.; Masopust, D.; Zhu, B.; Allison, J.P.; Sharpe, A.H.; Freeman, G.J.; Ahmed, R. Restoring function in exhausted CD8 T cells during chronic viral infection. Nature 2006, 439, $682-687$. [CrossRef] [PubMed]

48. Vali, B.; Jones, R.B.; Sakhdari, A.; Sheth, P.M.; Clayton, K.; Yue, F.Y.; Gyenes, G.; Wong, D.; Klein, M.B.; Saeed, S.; et al. HCV-specific T cells in HCV/HIV co-infection show elevated frequencies of dual Tim-3/PD-1 expression that correlate with liver disease progression. Eur. J. Immunol. 2010, 40, 2493-2505. [CrossRef]

49. Golden-Mason, L.; Palmer, B.E.; Kassam, N.; Townshend-Bulson, L.; Livingston, S.; McMahon, B.J.; Castelblanco, N.; Kuchroo, V.; Gretch, D.R.; Rosen, H.R. Negative immune regulator Tim-3 is overexpressed on $\mathrm{T}$ cells in hepatitis $\mathrm{C}$ virus infection and its blockade rescues dysfunctional CD4+ and CD8+ T cells. J. Virol. 2009, 83, 9122-9130. [CrossRef]

50. Kroy, D.C.; Ciuffreda, D.; Cooperrider, J.H.; Tomlinson, M.; Hauck, G.D.; Aneja, J.; Berger, C.; Wolski, D.; Carrington, M.; Wherry, E.J.; et al. Liver environment and HCV replication affect human T-cell phenotype and expression of inhibitory receptors. Gastroenterology 2014, 146, 550-561. [CrossRef] [PubMed]

51. Yang, Z.Z.; Grote, D.M.; Ziesmer, S.C.; Niki, T.; Hirashima, M.; Novak, A.J.; Witzig, T.E.; Ansell, S.M. IL-12 upregulates TIM-3 expression and induces T cell exhaustion in patients with follicular B cell non-Hodgkin lymphoma. J. Clin. Investig. 2012, 122, 1271-1282. [CrossRef]

52. Jin, H.T.; Anderson, A.C.; Tan, W.G.; West, E.E.; Ha, S.J.; Araki, K.; Freeman, G.J.; Kuchroo, V.K.; Ahmed, R. Cooperation of Tim-3 and PD-1 in CD8 T-cell exhaustion during chronic viral infection. Proc. Natl. Acad. Sci. USA 2010, 107, 14733-14738. [CrossRef] [PubMed] 
53. Nakamoto, N.; Cho, H.; Shaked, A.; Olthoff, K.; Valiga, M.E.; Kaminski, M.; Gostick, E.; Price, D.A.; Freeman, G.J.; Wherry, E.J.; et al. Synergistic reversal of intrahepatic HCV-specific CD8 T cell exhaustion by combined PD-1/CTLA-4 blockade. PLoS Pathog. 2009, 5, e1000313. [CrossRef]

54. Kaufmann, D.E.; Kavanagh, D.G.; Pereyra, F.; Zaunders, J.J.; Mackey, E.W.; Miura, T.; Palmer, S.; Brockman, M.; Rathod, A.; Piechocka-Trocha, A.; et al. Upregulation of CTLA-4 by HIV-specific CD4+ T cells correlates with disease progression and defines a reversible immune dysfunction. Nat. Immunol. 2007, 8, 1246-1254. [CrossRef]

55. Golden-Mason, L.; Burton, J.R., Jr.; Castelblanco, N.; Klarquist, J.; Benlloch, S.; Wang, C.; Rosen, H.R. Loss of IL-7 receptor alpha-chain (CD127) expression in acute HCV infection associated with viral persistence. Hepatology 2006, 44, 1098-1109. [CrossRef] [PubMed]

56. Mojumdar, K.; Vajpayee, M.; Chauhan, N.K.; Singh, A.; Singh, R.; Kurapati, S. Loss of CD127 \& increased immunosenescence of T cell subsets in HIV infected individuals. Indian J. Med. Res. 2011, 134, 972-981. [CrossRef] [PubMed]

57. Wherry, E.J.; Ha, S.J.; Kaech, S.M.; Haining, W.N.; Sarkar, S.; Kalia, V.; Subramaniam, S.; Blattman, J.N.; Barber, D.L.; Ahmed, R. Molecular signature of CD8+ T cell exhaustion during chronic viral infection. Immunity 2007, 27, 670-684. [CrossRef] [PubMed]

58. Grayson, J.M.; Zajac, A.J.; Altman, J.D.; Ahmed, R. Cutting edge: Increased expression of Bcl-2 in antigen-specific memory CD8+ T cells. J. Immunol. 2000, 164, 3950-3954. [CrossRef]

59. Bengsch, B.; Seigel, B.; Ruhl, M.; Timm, J.; Kuntz, M.; Blum, H.E.; Pircher, H.; Thimme, R. Coexpression of PD-1, 2B4, CD160 and KLRG1 on exhausted HCV-specific CD8+ T cells is linked to antigen recognition and T cell differentiation. PLoS Pathog. 2010, 6, e1000947. [CrossRef]

60. Johnston, R.J.; Comps-Agrar, L.; Hackney, J.; Yu, X.; Huseni, M.; Yang, Y.; Park, S.; Javinal, V.; Chiu, H.; Irving, B.; et al. The immunoreceptor TIGIT regulates antitumor and antiviral CD8(+) T cell effector function. Cancer Cell 2014, 26, 923-937. [CrossRef]

61. Chew, G.M.; Fujita, T.; Webb, G.M.; Burwitz, B.J.; Wu, H.L.; Reed, J.S.; Hammond, K.B.; Clayton, K.L.; Ishii, N.; Abdel-Mohsen, M.; et al. TIGIT Marks Exhausted T Cells, Correlates with Disease Progression, and Serves as a Target for Immune Restoration in HIV and SIV Infection. PLoS Pathog. 2016, 12, e1005349. [CrossRef]

62. Neumann-Haefelin, C.; Thimme, R. Adaptive immune responses in hepatitis C virus infection. Curr. Top. Microbiol. Immunol. 2013, 369, 243-262. [CrossRef] [PubMed]

63. Maylin, S.; Martinot-Peignoux, M.; Ripault, M.P.; Moucari, R.; Cardoso, A.C.; Boyer, N.; Giuily, N.; Castelnau, C.; Pouteau, M.; Asselah, T.; et al. Sustained virological response is associated with clearance of hepatitis C virus RNA and a decrease in hepatitis C virus antibody. Liver Int. 2009, 29, 511-517. [CrossRef] [PubMed]

64. Li, Y.; Wang, J.; Wang, J.; Xiao, Y.; Xu, B.; Li, H.; Yang, L.; Hao, X.; Ma, Y. SVR Rates of HCV-infected population under PEG-IFN-alpha/R treatment in Northwest China. Virol. J. 2017, 14, 62. [CrossRef]

65. Pearlman, B.L.; Traub, N. Sustained virologic response to antiviral therapy for chronic hepatitis $C$ virus infection: A cure and so much more. Clin. Infect. Dis. 2011, 52, 889-900. [CrossRef] [PubMed]

66. Jacobson, I.M.; McHutchison, J.G.; Dusheiko, G.; Di Bisceglie, A.M.; Reddy, K.R.; Bzowej, N.H.; Marcellin, P.; Muir, A.J.; Ferenci, P.; Flisiak, R.; et al. Telaprevir for previously untreated chronic hepatitis $\mathrm{C}$ virus infection. N. Engl. J. Med. 2011, 364, 2405-2416. [CrossRef] [PubMed]

67. Sherman, K.E.; Flamm, S.L.; Afdhal, N.H.; Nelson, D.R.; Sulkowski, M.S.; Everson, G.T.; Fried, M.W.; Adler, M.; Reesink, H.W.; Martin, M.; et al. Response-guided telaprevir combination treatment for hepatitis C virus infection. N. Engl. J. Med. 2011, 365, 1014-1024. [CrossRef] [PubMed]

68. Bacon, B.R.; Gordon, S.C.; Lawitz, E.; Marcellin, P.; Vierling, J.M.; Zeuzem, S.; Poordad, F.; Goodman, Z.D.; Sings, H.L.; Boparai, N.; et al. Boceprevir for previously treated chronic HCV genotype 1 infection. N. Engl. J. Med. 2011, 364, 1207-1217. [CrossRef] [PubMed]

69. Poordad, F.; McCone, J.; Bacon, B.R.; Bruno, S.; Manns, M.P.; Sulkowski, M.S.; Jacobson, I.M.; Reddy, K.R.; Goodman, Z.D.; Boparai, N.; et al. Boceprevir for untreated chronic HCV genotype 1 infection. N. Engl. J. Med. 2011, 364, 1195-1206. [CrossRef]

70. Werner, C.R.; Schwarz, J.M.; Egetemeyr, D.P.; Beck, R.; Malek, N.P.; Lauer, U.M.; Berg, C.P. Second-generation direct-acting-antiviral hepatitis C virus treatment: Efficacy, safety, and predictors of SVR12. World J. Gastroenterol. 2016, 22, 8050-8059. [CrossRef] 
71. Everson, G.T.; Sims, K.D.; Rodriguez-Torres, M.; Hézode, C.; Lawitz, E.; Bourlière, M.; Loustaud-Ratti, V.; Rustgi, V.; Schwartz, H.; Tatum, H.; et al. Efficacy of an interferon- and ribavirin-free regimen of daclatasvir, asunaprevir, and BMS-791325 in treatment-naive patients with HCV genotype 1 infection. Gastroenterology 2014, 146, 420-429. [CrossRef] [PubMed]

72. Elliot, L.N.; Lloyd, A.R.; Ziegler, J.B.; Ffrench, R.A. Protective immunity against hepatitis C virus infection. Immunol. Cell Biol. 2006, 84, 239-249. [CrossRef] [PubMed]

73. Van de Laar, T.J.; Molenkamp, R.; van den Berg, C.; Schinkel, J.; Beld, M.G.; Prins, M.; Coutinho, R.A.; Bruisten, S.M. Frequent HCV reinfection and superinfection in a cohort of injecting drug users in Amsterdam. J. Hepatol. 2009, 51, 667-674. [CrossRef] [PubMed]

74. Aitken, C.K.; Lewis, J.; Tracy, S.L.; Spelman, T.; Bowden, D.S.; Bharadwaj, M.; Drummer, H.; Hellard, M. High incidence of hepatitis $C$ virus reinfection in a cohort of injecting drug users. Hepatology 2008, 48, 1746-1752. [CrossRef] [PubMed]

75. Micallef, J.M.; Macdonald, V.; Jauncey, M.; Amin, J.; Rawlinson, W.; van Beek, I.; Kaldor, J.M.; White, P.A.; Dore, G.J. High incidence of hepatitis $\mathrm{C}$ virus reinfection within a cohort of injecting drug users. J. Viral Hepat. 2007, 14, 413-418. [CrossRef] [PubMed]

76. Grebely, J.; Conway, B.; Raffa, J.D.; Lai, C.; Krajden, M.; Tyndall, M.W. Hepatitis C virus reinfection in injection drug users. Hepatology 2006, 44, 1139-1145. [CrossRef]

77. Midgard, H.; Weir, A.; Palmateer, N.; Lo Re, V., 3rd; Pineda, J.A.; Macias, J.; Dalgard, O. HCV epidemiology in high-risk groups and the risk of reinfection. J. Hepatol. 2016, 65, S33-S45. [CrossRef]

78. Deterding, K.; Spinner, C.D.; Schott, E.; Welzel, T.M.; Gerken, G.; Klinker, H.; Spengler, U.; Wiegand, J.; Schulze Zur Wiesch, J.; Pathil, A.; et al. Ledipasvir plus sofosbuvir fixed-dose combination for 6 weeks in patients with acute hepatitis C virus genotype 1 monoinfection (HepNet Acute HCV IV): An open-label, single-arm, phase 2 study. Lancet Infect. Dis. 2017, 17, 215-222. [CrossRef]

79. Martinello, M.; Bhagani, S.; Gane, E.; Orkin, C.; Cooke, G.; Dore, G.J.; Petoumenos, K.; Applegate, T.L.; Tu, E.; Marks, P.; et al. Shortened therapy of eight weeks with paritaprevir/ritonavir/ombitasvir and dasabuvir is highly effective in people with recent HCV genotype 1 infection. J. Viral Hepat. 2018, 25, 1180-1188. [CrossRef] [PubMed]

80. Martinello, M.; Gane, E.; Hellard, M.; Sasadeusz, J.; Shaw, D.; Petoumenos, K.; Applegate, T.; Grebely, J.; Maire, L.; Marks, P.; et al. Sofosbuvir and ribavirin for 6 weeks is not effective among people with recent hepatitis C virus infection: The DARE-C II study. Hepatology 2016, 64, 1911-1921. [CrossRef]

81. Rockstroh, J.K.; Bhagani, S.; Hyland, R.H.; Yun, C.; Dvory-Sobol, H.; Zheng, W.; Brainard, D.M.; Ingiliz, P.; Lutz, T.; Boesecke, C.; et al. Ledipasvir-sofosbuvir for 6 weeks to treat acute hepatitis $C$ virus genotype 1 or 4 infection in patients with HIV coinfection: An open-label, single-arm trial. Lancet Gastroenterol. Hepatol. 2017, 2, 347-353. [CrossRef]

82. Osburn, W.O.; Snider, A.E.; Wells, B.L.; Latanich, R.; Bailey, J.R.; Thomas, D.L.; Cox, A.L.; Ray, S.C. Clearance of hepatitis $C$ infection is associated with the early appearance of broad neutralizing antibody responses. Hepatology 2014, 59, 2140-2151. [CrossRef] [PubMed]

83. Pestka, J.M.; Zeisel, M.B.; Blaser, E.; Schurmann, P.; Bartosch, B.; Cosset, F.L.; Patel, A.H.; Meisel, H.; Baumert, J.; Viazov, S.; et al. Rapid induction of virus-neutralizing antibodies and viral clearance in a single-source outbreak of hepatitis C. Proc. Natl. Acad. Sci. USA 2007, 104, 6025-6030. [CrossRef] [PubMed]

84. Post, J.J.; Pan, Y.; Freeman, A.J.; Harvey, C.E.; White, P.A.; Palladinetti, P.; Haber, P.S.; Marinos, G.; Levy, M.H.; Kaldor, J.M.; et al. Clearance of hepatitis $C$ viremia associated with cellular immunity in the absence of seroconversion in the hepatitis $C$ incidence and transmission in prisons study cohort. J. Infect. Dis. 2004, 189, 1846-1855. [CrossRef] [PubMed]

85. Zeisel, M.B.; Cosset, F.L.; Baumert, T.F. Host neutralizing responses and pathogenesis of hepatitis $C$ virus infection. Hepatology 2008, 48, 299-307. [CrossRef]

86. Fafi-Kremer, S.; Fauvelle, C.; Felmlee, D.J.; Zeisel, M.B.; Lepiller, Q.; Fofana, I.; Heydmann, L.; Stoll-Keller, F.; Baumert, T.F. Neutralizing antibodies and pathogenesis of hepatitis C virus infection. Viruses 2012, 4, 2016-2030. [CrossRef] [PubMed]

87. Ribeiro, R.M.; Li, H.; Wang, S.; Stoddard, M.B.; Learn, G.H.; Korber, B.T.; Bhattacharya, T.; Guedj, J.; Parrish, E.H.; Hahn, B.H.; et al. Quantifying the diversification of hepatitis C virus (HCV) during primary infection: Estimates of the in vivo mutation rate. PLoS Pathog. 2012, 8, e1002881. [CrossRef] 
88. Timpe, J.M.; Stamataki, Z.; Jennings, A.; Hu, K.; Farquhar, M.J.; Harris, H.J.; Schwarz, A.; Desombere, I.; Roels, G.L.; Balfe, P.; et al. Hepatitis C virus cell-cell transmission in hepatoma cells in the presence of neutralizing antibodies. Hepatology 2008, 47, 17-24. [CrossRef] [PubMed]

89. Osburn, W.O.; Fisher, B.E.; Dowd, K.A.; Urban, G.; Liu, L.; Ray, S.C.; Thomas, D.L.; Cox, A.L. Spontaneous control of primary hepatitis $\mathrm{C}$ virus infection and immunity against persistent reinfection. Gastroenterology 2010, 138, 315-324. [CrossRef] [PubMed]

90. Abdel-Hakeem, M.S.; Bédard, N.; Murphy, D.; Bruneau, J.; Shoukry, N.H. Signatures of protective memory immune responses during hepatitis C virus reinfection. Gastroenterology 2014, 147, 870.e878-881.e878. [CrossRef]

91. Nakamoto, N.; Kaplan, D.E.; Coleclough, J.; Li, Y.; Valiga, M.E.; Kaminski, M.; Shaked, A.; Olthoff, K.; Gostick, E.; Price, D.A.; et al. Functional restoration of HCV-specific CD8 T cells by PD-1 blockade is defined by PD-1 expression and compartmentalization. Gastroenterology 2008, 134, 1927-1937. [CrossRef]

92. Kared, H.; Fabre, T.; Bédard, N.; Bruneau, J.; Shoukry, N.H. Galectin-9 and IL-21 mediate cross-regulation between Th17 and Treg cells during acute hepatitis C. PLoS Pathog. 2013, 9, e1003422. [CrossRef] [PubMed]

93. Fuller, M.J.; Callendret, B.; Zhu, B.; Freeman, G.J.; Hasselschwert, D.L.; Satterfield, W.; Sharpe, A.H.; Dustin, L.B.; Rice, C.M.; Grakoui, A.; et al. Immunotherapy of chronic hepatitis C virus infection with antibodies against programmed cell death-1 (PD-1). Proc. Natl. Acad. Sci. USA 2013, 110, 15001-15006. [CrossRef] [PubMed]

94. Gardiner, D.; Lalezari, J.; Lawitz, E.; DiMicco, M.; Ghalib, R.; Reddy, K.R.; Chang, K.M.; Sulkowski, M.; Marro, S.O.; Anderson, J.; et al. A randomized, double-blind, placebo-controlled assessment of BMS-936558, a fully human monoclonal antibody to programmed death-1 (PD-1), in patients with chronic hepatitis C virus infection. PLoS ONE 2013, 8, e63818. [CrossRef] [PubMed]

95. Badr, G.; Bedard, N.; Abdel-Hakeem, M.S.; Trautmann, L.; Willems, B.; Villeneuve, J.P.; Haddad, E.K.; Sekaly, R.P.; Bruneau, J.; Shoukry, N.H. Early interferon therapy for hepatitis C virus infection rescues polyfunctional, long-lived CD8+ memory T cells. J. Virol. 2008, 82, 10017-10031. [CrossRef] [PubMed]

96. Abdel-Hakeem, M.S.; Bedard, N.; Badr, G.; Ostrowski, M.; Sekaly, R.P.; Bruneau, J.; Willems, B.; Heathcote, E.J.; Shoukry, N.H. Comparison of immune restoration in early versus late alpha interferon therapy against hepatitis C virus. J. Virol. 2010, 84, 10429-10435. [CrossRef] [PubMed]

97. Missale, G.; Pilli, M.; Zerbini, A.; Penna, A.; Ravanetti, L.; Barili, V.; Orlandini, A.; Molinari, A.; Fasano, M.; Santantonio, T.; et al. Lack of full CD8 functional restoration after antiviral treatment for acute and chronic hepatitis C virus infection. Gut 2012, 61, 1076-1084. [CrossRef] [PubMed]

98. Vertuani, S.; Bazzaro, M.; Gualandi, G.; Micheletti, F.; Marastoni, M.; Fortini, C.; Canella, A.; Marino, M.; Tomatis, R.; Traniello, S.; et al. Effect of interferon-alpha therapy on epitope-specific cytotoxic T lymphocyte responses in hepatitis $C$ virus-infected individuals. Eur. J. Immunol. 2002, 32, 144-154. [CrossRef]

99. Morishima, C.; Musey, L.; Elizaga, M.; Gaba, K.; Allison, M.; Carithers, R.L.; Gretch, D.R.; McElrath, M.J. Hepatitis C virus-specific cytolytic T cell responses after antiviral therapy. Clin. Immunol. 2003, 108, 211-220. [CrossRef]

100. Tatsumi, T.; Takehara, T.; Miyagi, T.; Nakazuru, S.; Mita, E.; Kanto, T.; Hiramatsu, N.; Hayashi, N. Hepatitis $\mathrm{C}$ virus-specific CD8+ T cell frequencies are associated with the responses of pegylated interferon- $\alpha$ and ribavirin combination therapy in patients with chronic hepatitis $C$ virus infection. Hepatol. Res. 2011, 41, 30-38. [CrossRef]

101. Kamal, S.M.; Fehr, J.; Roesler, B.; Peters, T.; Rasenack, J.W. Peginterferon alone or with ribavirin enhances HCV-specific CD4 T-helper 1 responses in patients with chronic hepatitis C. Gastroenterology 2002, 123, 1070-1083. [CrossRef]

102. Caetano, J.; Martinho, A.; Paiva, A.; Pais, B.; Valente, C.; Luxo, C. Differences in hepatitis C virus (HCV)-specific CD8 T-cell phenotype during pegylated alpha interferon and ribavirin treatment are related to response to antiviral therapy in patients chronically infected with HCV. J. Virol. 2008, 82, 7567-7577. [CrossRef] [PubMed]

103. Erickson, S.; Sangfelt, O.; Castro, J.; Heyman, M.; Einhorn, S.; Grander, D. Interferon-alpha inhibits proliferation in human $\mathrm{T}$ lymphocytes by abrogation of interleukin 2-induced changes in cell cycle-regulatory proteins. Cell Growth Differ. 1999, 10, 575-582. [PubMed]

104. Bogdan, C. The function of type I interferons in antimicrobial immunity. Curr. Opin. Immunol. 2000, 12, 419-424. [CrossRef] 
105. Marshall, H.D.; Urban, S.L.; Welsh, R.M. Virus-induced transient immune suppression and the inhibition of T cell proliferation by type I interferon. J. Virol. 2011, 85, 5929-5939. [CrossRef] [PubMed]

106. Martin, B.; Hennecke, N.; Lohmann, V.; Kayser, A.; Neumann-Haefelin, C.; Kukolj, G.; Bocher, W.O.; Thimme, R. Restoration of HCV-specific CD8+ T cell function by interferon-free therapy. J. Hepatol. 2014, 61, 538-543. [CrossRef]

107. Burchill, M.A.; Golden-Mason, L.; Wind-Rotolo, M.; Rosen, H.R. Memory re-differentiation and reduced lymphocyte activation in chronic HCV-infected patients receiving direct-acting antivirals. J. Viral Hepat. 2015, 22, 983-991. [CrossRef]

108. Emmanuel, B.; El-Kamary, S.S.; Magder, L.S.; Stafford, K.A.; Charurat, M.E.; Poonia, B.; Chairez, C.; McLaughlin, M.; Hadigan, C.; Masur, H.; et al. Immunological recovery in T-cell activation after sustained virologic response among HIV positive and HIV negative chronic Hepatitis C patients. Hepatol. Int. 2019. [CrossRef]

109. Wieland, D.; Kemming, J.; Schuch, A.; Emmerich, F.; Knolle, P.; Neumann-Haefelin, C.; Held, W.; Zehn, D.; Hofmann, M.; Thimme, R. TCF1+ hepatitis C virus-specific CD8+ T cells are maintained after cessation of chronic antigen stimulation. Nat. Commun. 2017, 8, 15050. [CrossRef] [PubMed]

110. Zhang, C.; Hua, R.; Cui, Y.; Wang, S.; Yan, H.; Li, D.; Zhang, Y.; Tu, Z.; Hao, P.; Chen, X.; et al. Comprehensive mapping of antigen specific $T$ cell responses in hepatitis $C$ virus infected patients with or without spontaneous viral clearance. PLoS ONE 2017, 12, e0171217. [CrossRef]

111. Comarmond, C.; Garrido, M.; Pol, S.; Desbois, A.C.; Costopoulos, M.; Le Garff-Tavernier, M.; Si Ahmed, S.N.; Alric, L.; Fontaine, H.; Bellier, B.; et al. Direct-Acting Antiviral Therapy Restores Immune Tolerance to Patients With Hepatitis C Virus-Induced Cryoglobulinemia Vasculitis. Gastroenterology 2017, 152, 2052.e2052-2062.e2052. [CrossRef]

112. Sarasin-Filipowicz, M.; Oakeley, E.J.; Duong, F.H.; Christen, V.; Terracciano, L.; Filipowicz, W.; Heim, M.H. Interferon signaling and treatment outcome in chronic hepatitis C. Proc. Natl. Acad. Sci. USA 2008, 105, 7034-7039. [CrossRef]

113. Honda, M.; Sakai, A.; Yamashita, T.; Nakamoto, Y.; Mizukoshi, E.; Sakai, Y.; Nakamura, M.; Shirasaki, T.; Horimoto, K.; Tanaka, Y.; et al. Hepatic ISG expression is associated with genetic variation in interleukin 28B and the outcome of IFN therapy for chronic hepatitis C. Gastroenterology 2010, 139, 499-509. [CrossRef]

114. Chen, L.; Borozan, I.; Feld, J.; Sun, J.; Tannis, L.L.; Coltescu, C.; Heathcote, J.; Edwards, A.M.; McGilvray, I.D. Hepatic gene expression discriminates responders and nonresponders in treatment of chronic hepatitis C viral infection. Gastroenterology 2005, 128, 1437-1444. [CrossRef]

115. Holmes, J.A.; Carlton-Smith, C.; Kim, A.Y.; Dumas, E.O.; Brown, J.; Gustafson, J.L.; Lauer, G.M.; Silva, S.T.; Robidoux, M.; Kvistad, D.; et al. Dynamic changes in innate immune responses during direct-acting antiviral therapy for HCV infection. J. Viral Hepat. 2019, 26, 362-372. [CrossRef]

116. Corado, J.; Toro, F.; Rivera, H.; Bianco, N.E.; Deibis, L.; De Sanctis, J.B. Impairment of natural killer (NK) cytotoxic activity in hepatitis C virus (HCV) infection. Clin. Exp. Immunol. 1997, 109, 451-457. [CrossRef]

117. Fauriat, C.; Long, E.O.; Ljunggren, H.G.; Bryceson, Y.T. Regulation of human NK-cell cytokine and chemokine production by target cell recognition. Blood 2010, 115, 2167-2176. [CrossRef]

118. De Maria, A.; Bozzano, F.; Cantoni, C.; Moretta, L. Revisiting human natural killer cell subset function revealed cytolytic CD56(dim)CD16+ NK cells as rapid producers of abundant IFN-gamma on activation. Proc. Natl. Acad. Sci. USA 2011, 108, 728-732. [CrossRef]

119. Ahlenstiel, G.; Martin, M.P.; Gao, X.; Carrington, M.; Rehermann, B. Distinct KIR/HLA compound genotypes affect the kinetics of human antiviral natural killer cell responses. J. Clin. Investig. 2008, 118, 1017-1026. [CrossRef] [PubMed]

120. Cooper, M.A.; Fehniger, T.A.; Caligiuri, M.A. The biology of human natural killer-cell subsets. Trends Immunol. 2001, 22, 633-640. [CrossRef]

121. Poli, A.; Michel, T.; Thérésine, M.; Andrès, E.; Hentges, F.; Zimmer, J. CD56bright natural killer (NK) cells: An important NK cell subset. Immunology 2009, 126, 458-465. [CrossRef] [PubMed]

122. Miyagi, T.; Shimizu, S.; Tatsumi, T.; Nishio, K.; Hiramatsu, N.; Kanto, T.; Hayashi, N.; Takehara, T. Differential alteration of CD56(bright) and CD56 (dim) natural killer cells in frequency, phenotype, and cytokine response in chronic hepatitis C virus infection. J. Gastroenterol. 2011, 46, 1020-1030. [CrossRef] [PubMed] 
123. Nakamura, I.; Furuichi, Y.; Sugimoto, K. Restoration of natural killer cell activity by interferon-free direct-acting antiviral combination therapy in chronic hepatitis C patients. Hepatol. Res. 2018, 48, 855-861. [CrossRef] [PubMed]

124. MacParland, S.; Cherepanov, V.V.L.; Gamil, M.; Beumont, M.; Yoon, S.; Rahman, A.; Capraru, C.; Ostrowski, M.; Brahmania, M.; Wong, D.; et al. Rapid Intrahepatic and Peripheral Blood HCV RNA Decline and HCV-Specific Immune Response Increase During IFN-Free DAA Therapy in HCV Treatment-Naive Patients. J. Can. Assoc. of Gastroenterol. 2018, 1, 284-285. [CrossRef]

125. Kanwal, F.; Kramer, J.; Asch, S.M.; Chayanupatkul, M.; Cao, Y.; El-Serag, H.B. Risk of Hepatocellular Cancer in HCV Patients Treated With Direct-Acting Antiviral Agents. Gastroenterology 2017, 153, 996.e1001-1005.e1001. [CrossRef] [PubMed]

(C) 2019 by the authors. Licensee MDPI, Basel, Switzerland. This article is an open access article distributed under the terms and conditions of the Creative Commons Attribution (CC BY) license (http://creativecommons.org/licenses/by/4.0/). 